\title{
Husband's Support is Needed to Prevent Postpartum Depression
}

\author{
Ni Ketut Alit Armini \\ Faculty of Nursing Universitas Airlangga \\ Surabaya, Indonesia \\ nk.alita@fkp.unair.ac.id
}

\author{
Rr Dian Tristiana \\ Faculty of Nursing Universitas Airlangga \\ Surabaya, Indonesia \\ Agnes Ose Tokan \\ Faculty of Nursing Universitas Airlangga \\ Surabaya, Indonesia
}

\begin{abstract}
Husband's support was a factor which helps women in postpartum depression. Husband's support is facing a problem with local culture where the husband cannot give a proper support for his wife. This study aimed to analyze the relationship between Husband's support and postpartum depression. Research design was cross-sectional study among mother in the postpartum period. This study involved 49 samples taken by consecutive sampling. The independent variable was Husband's support, and the dependent variable was postpartum depression. Data were collected by questionnaire then analyzed by Spearman Rho with $\alpha \leq$ 0.05. There were 42,9 \% respondents who got moderate Husband's support and did not experience postpartum depression. Whereas $36,7 \%$ respondents with low Husband's support indicated experiencing postpartum depression. Spearman rank rho statistical test result $p=$ 0,007. It means there was a significant relationship between Husband's support and postpartum depression; relation coefficient was $(r=\mathbf{- 0 , 6 0 0})$, it means there was a strong correlation. To conclude, the higher Husband's support significantly related to a decreasing postpartum depression. This study suggested for health care to optimize the role of husband as a source of support to prevent postpartum depression for his beloved wife. Further research should observe interventions which can optimize Husband's support preventing postpartum depression.
\end{abstract}

Keywords: husband's support, postpartum depression

\section{INTRODUCTION}

The postpartum period is a time when a woman feels so happy and stressful at the same time. The woman in the postpartum period are likely to experience stress and have to face adaptation process to be a mother so that this period can cause postpartum depression [1]. Postpartum depression is an unpredictable condition in women who experience it. This condition causes sadness, anger, hate, resentment, even desperate for a woman who has just given birth, so it makes difficult to carry out their role [2]. A mother experiencing postpartum depression has symptoms of behavioral changes such as being quiet, crying, excessive anxiety, insomnia, and weight changes. Social support, especially from her husband and family, is one of the factors of postpartum depression [3], [4];[5] The lack of husband's support for giving attention, communication, emotionally relationship are triggers of postpartum depression (4) [6]. In Ile Boleng, the husband has a role as a leader in the family so they should work in the city, and also they are not allowed to do housework like cooking or washing clothes. These habits are caused by its culture that men have a higher position than women, the issue of pregnancy and childbirth has become women's nature.

Postpartum depression case, according to a WHO report in Soep (2009), women who give birth and experience low depression are at 10 per 1,000 live births, and moderate or severe postpartum depression are at 30 to 200 per 1,000 live births. The postpartum depression case in Asia is quite high and very varied from 26 to $85 \%$ of postpartum women [4]). The prevalence of depressed mothers in Indonesia at $63.3 \%$, with a moderate level of depression. The observation by Coordinating Midwife Puskesmas Ile Boleng indicated there is a behavioral change at three of five postpartum mothers. They are more silent, mushy, and exhausted.

Many factors cause postpartum depression case, namely: hormonal, age, parity, pregnancy experience and childbirth, education level, marital status, unwanted pregnancy, a history of psychiatric disorders, socioeconomic, and social support. There are several internal and external factors causing postpartum depression, which are the mother's age at giving birth, occupation, education, age at marriage, pregnancy history, labor history, history of breastfeeding, postpartum massage history, and family support [5]. Postpartum depression has a negative impact on the health of mothers, children, and families. Mothers who experience postpartum 
depression will have less interest in their baby. Mothers often respond negatively to her baby during crying, the gaze or gestures. Further impact is mothers are not able to optimally care for their babies, including being lazy to breastfeed [8].

It is important to find out the treatment for caring mothers, children and families from the psychological disorders. Schepper in 2016 developed the concept and model to emphasize the importance of father's role. Mercer stated that a father could reduce tensions between mother and baby. The role of mother parenting is achieved through the interaction of father [9]. Support family can reduce depression faced by women during the postpartum period. Women who feel being valued, cared and loved by her husband and family will not feel less valuable so that it can prevent a symptom of depression [5]. Husband's support is one of the factors that can help women who experience postpartum depression.

Indonesian's women who have experienced postpartum depression stated that husbands' support contributes significantly to their healing. Kleiman, [10] stated that postpartum depression after giving birth could be overcome by practical and emotional. Affection and attention of her husband are one of them. Mothers suffering from postpartum depression can not heal themselves. Thus it requires husband and family members to understand and cooperate. Helping to do housework to release stress and fatigue and handling the baby is the way to decrease mother's burden [11].

\section{METHODS}

\section{A. Design}

This research uses descriptive analytic design with cross-sectional approach. The research population is a mother1 with postpartum depression at Puskesmas Ile Boleng East Flores, NTT. The amount of sample was 49 respondents by[2] purposive sampling.

\section{B. Data Collection and Analysis}

The independent variables in this study were the husband's support, while the dependent variable was postpartum depression case. A study conducted by the study protocol that approved by health research ethics committee of Faculty of Nursing Airlangga University No. 271-KEPK. Data was collected by using questionnaire. Support husband used Source of Social Support Scale -Partner (SSSS-P) obtained from Measurement Instrument Database for the Social Science (MIDS). SSSS-P consists of 10 items of questions. Questionnaires postpartum depression applied the Edinburgh Postpartum Depression Scale (EPDS) which is developed by Scottish health centers in Edinburgh and Livingston. It consists of 10 items of questions. Analysis adapted the Spearman Rho with significance level $\alpha \leq 0.05$.

\section{RESULTS}

Table 1. Demographic Data of Respondents About Husband;s Support with Postpartum Depression $(n=49)$

\begin{tabular}{|c|c|c|c|}
\hline $\begin{array}{l}\text { Characteris } \\
\text { tic }\end{array}$ & Indicator & $f$ & $\%$ \\
\hline \multirow[t]{3}{*}{ Age } & $<20$ years & 8 & 17 \\
\hline & $21-35$ years & 35 & 71 \\
\hline & $>35$ years & 6 & 12 \\
\hline \multirow[t]{3}{*}{ Occupation } & Housewife & 43 & 88 \\
\hline & $\begin{array}{l}\text { Government } \\
\text { official }\end{array}$ & 4 & 8 \\
\hline & Farmer & 2 & 4 \\
\hline Level & Elementary & 17 & 35 \\
\hline \multirow[t]{3}{*}{ Education } & Junior & 15 & 30 \\
\hline & Senior & 14 & 28 \\
\hline & University & 3 & 7 \\
\hline \multirow[t]{3}{*}{ Parity } & Primipara & 16 & 33 \\
\hline & Multipara & 32 & 65 \\
\hline & Grand multipara & 1 & 2 \\
\hline
\end{tabular}

All respondents were from the tribe of Flores NTT. None had a history of concomitant diseases during pregnancy and giving birth, and have no depression history. Most respondents are between 21 and 35 years (71\%), mostly working as housewives (88\%), and the most dominating education is an elementary school (35\%). Most multiparous $(65 \%)$.

Table 2 Relationship Support The husband and the incidence of Postpartum Depression $(n=49)$

\begin{tabular}{lllllll} 
Husband's & \multicolumn{2}{l}{ Post-Partum Depression } & & \multicolumn{2}{c}{ Totaly } \\
\cline { 2 - 5 } Support & No & \multicolumn{3}{c}{ Yes } & & \\
\cline { 2 - 5 } & $\mathrm{f}$ & $\%$ & $\mathrm{f}$ & $\%$ & 2 & $\%$ \\
High & 9 & 18,4 & 1 & 2,0 & 10 & 20,4 \\
Medium & 20 & 40,8 & 1 & 2,0 & 21 & 42,8 \\
Low & 5 & 10,2 & 13 & 26,6 & 18 & 36,8 \\
Totally & 34 & 69,4 & 15 & 30,6 & 49 & 100 \\
Spearman Rho & $\mathrm{r}=-0,600$ & $p=0,000$ & & & &
\end{tabular}

Most respondents got a medium category for husband's support with a percentage of $42.9 \%$. It shows that mothers who did not experience postpartum depression are dominating there. It reached $69 \%$. Respondents getting the support of her husband at medium level did not experience postpartum depression. Result Spearman Rho p-value $=0.000(\alpha \leq 0.05)$ which means the hypothesis (H1) is accepted. There is a significant relationship between husband support and postpartum depression case. A positive correlation coefficient value $r=-0.600$, which means there is a strong correlation. If the husband's support is high, postpartum depression will not occur.

\section{DISCUSSION}

There were 21 respondents as much as $42.9 \%$ of samples getting the support of her husband in the medium category while the high category of husband's support was only involved ten respondents $(20.4 \%)$ and the remaining 18 
respondents took place in the low category (3.7\%). Most types of support provided by the husband were emotional support, providing insurance, encouragement, and affection after giving birth, a good listener and understanding his wife' feeling of worries. Husband also help his wife to provide households, accompany his wife while traveling. However, husband's support indicated low level when they were avoiding problems post giving birth, and changing the subject while talking.

Mercer Theory (1989) stated the concept of maternal postpartum maternal Role Attaintment. This concept describes an interplay approachment (interactions) where people around the mother, including her husband, family, and others will influence the former's doing to achieve their goals, which is their role as a mother. The amount of support in the medium category is a strong bond among partners while giving birth and postpartum. Furthermore, the research results in the total number of women who got low support's husband in small proportion. There were many factors influencing the husband's support. Prayoga (2016) revealed that the husband's support is influenced by three factors, namely: closeness, self-esteem and social skills.

Culture in Ile Boleng caused low category of support's husband; they believed husband's response was to earn money for living. Husbands were not allowed to do housework like cooking or washing clothes. All household tasks were wife's responsibility. People thought that men were higher position than women so that it became problems during pregnancy and giving birth to a woman. Culture is the unwritten norm that is trusted and obeyed by people. It led to a lack of attention even husband should devote their affection his wife. This cultural isolation did not support the provision of optimally husband's support. Referring to research [12] that the husband's support characteristics are influenced by age, education, knowledge, culture.

There were 34 respondents $(69 \%)$ who did not experience postpartum depression and the remaining, 15 respondents $(31 \%)$, experiencing postpartum depression. The incidence of postpartum depression is a psychological disorder in mothers that involved various support systems.

Mother's role Attainment proposed by Mercer is a cycle of the microsystem, mesosystem, and macro system. The microsystem is the immediate environment in which the role of the mother reaches the achievement. Microsystem Components are a family function, mother-father relationship, social support, economic status, family trust and stressor newborn. It is believed as an inherent individual within the family system. Mesosystem consists of daily cares, schools, workplaces, places of worship and the environment in society. Macrosystem consists of political, social and environmental health service with the health policies affecting on the maternal role.

The low rate of postpartum depression case is likely to be influenced by the previous history of depression and complications history during pregnancy. History of depression increases the risk of recurrence during the period of maternal postpartum depression. If there are obstacles during pregnancy, it will cause stress to the mother. Moreover, also if mother's coping is inadequate, it will easily lead to psychological disorders such as stress, anxiety, and depression.

This opinion supported by the Health and the National Medical Research Council (NHMRC), which has categorized the risk factors into four categories based on supporting evidence. These four categories are risk factors which are certainly obtained (a history of depression, depression during pregnancy, marital relationships, lack of support and stressful life), risk factors can be obtained (a family history of psychotic disorders, personality characteristics, negative cognitive function, giving birth experience, and obstetric complications, baby's health, neurotransmitter), risk factors may be acquired (thyroid dysfunction, premature and sexual abuse of children) and protective factors (self-esteem, improved support).

Several respondents who had a husband's support in medium and high categories did not experience postpartum depression. There were nearly a half of the respondents with Husband's support low category experiencing postpartum depression. [6] outlined that postpartum depression related to the lack of social support (especially from spouse). Husband's support can reduce postpartum depression and acts as a shield between the potential stress and parenting. It also affects positively on women's experiences of maternity and prevention of depression. Also, according to the Becoming Mothers Theory by Mercer, becoming a mom means taking a new identity by rethinking and redefining about herself. Mercer uses the interaction approach (interactionist) in understanding the process by which someone acts in particular role depends on the reaction and interaction experienced by people around her, especially from spouses.

Although most respondents got high husband's support, they were also experiencing postpartum depression. These events related to parity factor, employment, and education. Respondents who experienced postpartum depression with the high support of her husband suffered from parity primiparas, some others with grand multipara parity. Parity Primiparous history was associated with the first experience of individuals facing maternity thus increasing the risk of the incidence of postpartum depression. In the history of parity grand multipara related to the level of stress mothers who repeatedly give birth, are also possible due to the increasing number of dependent children.

A statistical test of Spearman rho rank hypothesis (H1) is accepted that there is a significant relationship between husband's support and postpartum depression. The strength of the relationship in every variable resulted in coefficient correlation at 0.600 which means it has a strong correlation. The postpartum depression factor is determined from weak to the strong category. The quality of relationships with partners as social support of her husband has a strong effect in preventing the postpartum depression. 


\section{CONCLUSION}

Most respondents got medium husband's support, which is emotional support. Respondents who got medium husband's support category did not experience postpartum depression, but a small number of respondents with the support of her husband in the low category experience postpartum depression. In addition, husband's support prevents postpartum depression such as emotional support, informational, instrumental, and award. Optimizing the role of family, especially her husband as a source of social support, increasing the intensity and variety of social support completely. Secondly, health care should provide information to husbands and families so they can give social support optimally especially when his wife is in the postpartum period. Thirdly, the policy of the health department as well as cooperation with the relevant departments that support husbands to gain support and help the wife (husband standby), especially during pregnancy, give birth, and postpartum. Fourthly, future researcher can assess the interventions which can increase participation in husband involvement in supporting a wife to reduce postpartum depression

\section{REFERENCES}

[1] S. De Schepper, T. Vercauteren, J. Tersago, Y. Jacquemyn, F. Raes, and E. Franck, "Post-Traumatic Stress Disorder after childbirth and the influence of maternity team care during labour and birth: A cohort study," Midwifery, vol. 32, pp. 87-92, 2016.

[2] S. Elvira, Depresi pasca persalinan. Jakarta: FK UI, 2006.

[3] B. C. Mullany, S. Becker, and M. J. Hindin, "The impact of including husbands in antenatal health education services on maternal health practices in urban Nepal: results from a randomized controlled trial," Health Educ. Res., vol. 22, no. 2, pp. 166-176, 2007.
[4] B. C. Mullany, "Barriers to and attitudes towards promoting husbands' involvement in maternal health in Katmandu, Nepal," Soc. Sci. Med., vol. 62, no. 11, pp. 2798-2809, 2006.

[5] S. Wahyuni, Murwati, and Supiati, "Faktor Internal dan eksternal Yang Memengaruhi Depresi Postpartum," J. Terpadu ilmu Kesehat., vol. 3 No.2, pp. 131-137, 2014.

[6] S. Urbayatun, "Dukungan Social Dan Kecenderungan Depresi Post Partum Pada Ibu Primipara Di Daerah Gempa Bantul,” HUMANITAS (Jurnal Psikologi Indonesia), vol. 7, no. 2. pp. 114-122, 2012.

[7] C. El-Hachem et al., "Early identification of women at risk of postpartum depression using the Edinburgh Postnatal Depression Scale (EPDS) in a sample of Lebanese women," BMC Psychiatry, vol. 14, no. 1, p. 242, 2014.

[8] P. Almond, "Postnatal depression: A global public health perspective," Perspect. Public Health, vol. 129, no. 5, pp. 221-227, 2009.

[9] A. Rahmandi, Strategi Penanggulangan (Coping) pada Ibu yang Mengalami Postpartum Blues di RSUD Kota Semarang. Semarang: Skripsi Fakultas Psikologi Universitas Diponegoro, 2007.

[10] S. Rizky, Hubungan Antara Dukungan Sosial Dengan Kecenderungan Postpartum di Pundong Bantul Yogyakarta. Yogyakarta: Fakultas Psikologi UAD, 2016.

[11] Y. Amelia, Effect of Family Violance and Parental Psychopathology on The psychological Outcomes of Urban. Yogyakarta: Gajah Mada University, 2014.

[12] C. Suryawati, "Faktor Sosial Budaya dalam Praktik Perawatan Kehamilan , Persalinan, dan Pasca Persalinan ( Studi di Kecamatan Bangsri Kabupaten Jepara )," J. Promosi Kesehat. Indones., vol. 2, no. 1, pp. 21-31, 2007. 